\title{
THE EFFECT OF PHYTASE ENZYMES ADDITION ON ARTIFICIAL FEED ON HOVEN'S CARP GROWTH, Leptobarbus hoevenii (Bleeker, 1851)
}

\author{
Nora Sintia*1, Deny Sapto Chondro Utomo, Indra Gumay Yudha*2
}

\begin{abstract}
Hoven's carp is a freshwater fish found in Indonesian. This study aims to study the effect of the addition of phytase enzymes with different doses on commercial feed on the growth rate of hoven's carp and determine the dose of the phytase enzyme that is best for the growth of sooty fish. This research was conducted for 70 days at the Fisheries Cultivation Laboratory, Department of Fisheries and Marine Resources, Faculty of Agriculture, University of Lampung. This study used a completely randomized design with 4 treatments and 3 replications. treatment $A$ without the administration of phytase enzymes, $B$ giving phytase enzymes $250 \mathrm{mg} / \mathrm{kg}$ of feed, $C$ giving phytase enzymes $500 \mathrm{mg} / \mathrm{kg}$ feed, $D$ giving phytase enzymes $750 \mathrm{mg} / \mathrm{kg}$ offeed. The parameters observed were absolute length growth, absolute weight growth, daily growth rate, SR, FCR, and protein retention. The results showed that the administration of phytase enzymes had an effect on fish growth with a dose of phytase enzyme $750 \mathrm{mg} / \mathrm{kg}$ of feed showing good results.
\end{abstract}

Keywords: hoven's carp, phytase enzymes, growth

\section{Pendahuluan}

Ikan jelawat Leptobarbus hoeveni (Blkr, 1851) merupakan ikan air tawar yang ditemukan di perairan umum Indonesia, seperti di Sumatera dan Kalimantan. Ikan jelawat juga dapat dijumpai di kawasan Asia Tenggara, seperti negara tetangga Malaysia, Brunei, Vietnam, Thailand, dan Kamboja. Di kawasan tersebut ikan jelawat mendiami area anak sungai, dan daerah genangan kawasan hulu hingga hilir, bahkan di muara sungai yang berlubuk dan berhutan di pinggirnya.

Ikan jelawat ini sangat digemari oleh masyarakat Malaysia dan Brunei. Hal tersebut menjadikan ikan jelawat memiliki permintaan pasar yang cukup tinggi. Untuk memenuhi kebutuhan pasar dikirim sebanyak 25 ton/bulan (Sunarno, 2001).

Dikarenakan kebutuhan pasar yang tinggi pembudidayaan ikan jelawat perlu dilakukan. Pembudidayaan tersebut diharapkan agar populasi ikan jelawat tidak mengalami penurunan yang

\footnotetext{
${ }^{1}$ E-mail: norasintia912@yahoo.co.id

2 Jurusan Perikanan dan Kelautan, Fakultas Pertanian, Universitas Lampung

Jl. Prof. S. Brodjonegoro No.1 Gedong Meneng Bandar Lampung, 35145
} 
diakibatkan oleh penangkapan terus menerus. Penurunan jumlah ikan jelawat di alam mendorong minat masyarakat untuk mengembangkan budidayanya sebagai sebuah alternatif usaha dan sekaligus melakukan upaya pelestarian plasma nutfah ikan asli perairan Indonesia .

Pertumbuhan ikan jelawat yang lamban merupakan permasalahn pada saat pembudidayaan ikan jelawat. Hal ini membuat masyarakat enggan untuk mem-budidayakannya dan lebih memilih jenis ikan lain yang masa pertumbuhannya lebih cepat serta menghasilkan keuntungan yang lebih tinggi. Pertumbuhan ikan jelawat diperkirakan $9-10$ bulan sehingga menyebabkan pakan yang dikonsumsinya juga sangat tinggi (Aryani, 2005 dalam Aryani et al., 2009).

Pertumbuhan ikan yang lambat salah satunya diakibatkan karena di dalam pakan terdapat salah satu bahan nabati contohnya seperti tepung bungkil kedelai dengan kandungan protein yaitu sekitar $42 \%$ yang mempunyai serat kasar yang tinggi. Bungkil kedelai tersebut mengandung zat antinutrisi atau asam fitat. Kemampuan asam fitat yang tinggi mampu mengikat mineral seperti kalsium, magnesium, seng, tembaga, besi, dan kalium, sehingga membuat penyerapan dan pencernaan ikan terganggu (Kumar et al. 2011).

Salah satu upaya untuk mengatasi hal tersebut adalah dengan menambahkan enzim fitase dalam pakan sehingga, diharapkan dapat menghambat zat antinutrisi dan meningkatkan penyerapan serta mengatur ekskresi nutrien (fosfor, nitrogen, dan mineral). Selain itu enzim fitase dapat menghidrolisis asam fitat cadangan unsur fosfat yang terdapat dalam pakan sehingga menjadi inositol serta asam fosfat. Pengaplikasian enzim fitase telah banyak dibuktikan mampu meningkatkan pertumbuhan beberapa jenis ikan seperti ikan nila $(O$. niloticus) (Rachmawati dan Samidjan, 2014), ikan baung (Mystus nemurus) (Rochmawati et al., 2016), dan kerapu macan (E. fuscoguttatus (Rachmawati, 2001). Berdasarkan hal tersebut penelitian mengenai pemberian enzim fitase dengan dosis yang berbeda perlu dilakukan untuk mengetahui pengaruhnya terhadap pertumuhan, kelulus-hidupan dan penentuan dosis terbaik pada ikan jelawat.

\section{Metode}

\section{Waktu dan Tempat}

Penelitian ini dilakukan pada bulan Oktober - Desember 2018 di Laboratorium Budidaya Perikanan, Jurusan Perikanan dan Kelautan, Fakultas Pertanian, Universitas Lampung.

\section{Alat dan Bahan}

Alat yang digunakan dalam penelitian ini yaitu kolam terpal sebanyak 12 buah berukuran $1,5 \times 1 \times$ $0,5 \mathrm{~m}^{3}$, waring, saringan, ember, timbangan digital, $\mathrm{pH}$ meter, termometer, DO test-kit, alat tulis, plastik zip, penggaris, scoopnet, spray, dan kamera.

Bahan yang digunakan dalam penelitian ini meliputi benih ikan jelawat yang digunakan berasal dari BBAT Jambi sebanyak 180 ekor dengan ukuran benih $5-7 \mathrm{~cm}$ dan berat 5 g/ekor yang berumur 3 bulan. Penelitian diawali dengan 
penambahan enzim fitase pada pakan komersil dengan dosis yang berbedabeda untuk pertumbuhan ikan jelawat.

\section{Rancangan Percobaan}

Rancangan penelitian yang digunakan adalah rancangan acak lengkap (RAL) dengan 4 perlakuan yang masing-masing perlakuan terdiri dari 3. Perlakuan yang digunakan yaitu A (tanpa enzim fitase), B (enzim fitase $250 \mathrm{mg} / \mathrm{kg}$ pakan), C (enzim fitase $500 \mathrm{mg} / \mathrm{kg}$ pakan), dan D (enzim fitase $750 \mathrm{mg} / \mathrm{kg}$ pakan).

\section{Persiapan Wadah dan Media} Pemeliharaan

Wadah penampungan ikan jelawat berupa kolam berukuran $2 \times 4$ $\times 1 \mathrm{~m}^{3}$, yang diisi air setinggi \pm 30 cm.dan dibiarkan selama 3 hari kemudian kan jelawat diaklimatisasi selama 1 minggu sebelum perlakuan. Wadah pemeliharaan yang akan digunakan berupa kolam 1 buah yang terlebih dahulu dibersihkan dan dikeringkan kemudian disekat menjadi 12 petak, dengan ukuran 1,5 $\times 1 \times 0,5 \mathrm{~m}^{3}$. Penebaran benih dilakukan pada pagi hari. Benih yang ditebar berukuran 7-9 $\mathrm{cm}$ dimasukkan ke dalam kolam yang sudah disekat dengan padat tebar 15 ekor/petak. Pemeliharaan benih ikan jelawat dilakukan selama 70 hari.

\section{Pemberian Enzim Fitase melalui Pakan Komersil}

Persiapan pakan buatan yang akan digunakan, Pakan kontrol ditambahkan kuning telur sebanyak $20 \mathrm{mg} / \mathrm{kg}$ pakan. Enzim fitase ditimbang dengan dosis masingmasing sesuai dengan perlakuan yakni dosis 250,500 , dan $700 \mathrm{mg} / \mathrm{kg}$ pakan dan dilarutkan dalam larutan
PBS sebanyak $100 \mathrm{ml}$ tiap dosis perlakuan yang berfungsi sebagai pengencer dan ditambahkan putih telur sebanyak $20 \mathrm{mg} / \mathrm{kg}$ pakan berfungsi sebagai binder. Larutan yang telah tercampur dimasukkan ke dalam sprayer dan pakan disemprot dengan larutan enzim fitase yang telah dipersiapkan sebelumnya, pakan yang telah diberi enzim fitase kemudian didiamkan selama 24 jam dalam wadah tertutup. Pakan uji yang telah dibuat kemudian diuji coba ke stok benih ikan jelawat yang ada. Hal ini bertujuan untuk mengujikan pakan apakah pakan yang telah dibuat dapat dan mau dimakan oleh ikan.

\section{Pemberian Pakan}

Pakan yang diberikan selama pemeliharaan adalah pakan pelet dengan frekuensi pemberian pakan tiga kali sehari pada pukul 08:00 WIB, 12.00 WIB, dan 16.00 WIB sebanyak $5 \%$ dari bobot biomassa.

\section{Sampling}

Sampel Sampling partumbuhan dalam penelitian ini diambil sebanyak 10 ekor/ulangan yang dihitung panjang dan berat tubuhnya. Sampling dilakukan setiap 7 hari sekali.

\section{Parameter Penelitian}

Pertumbuhan Panjang Mutlak

Pertumbuhan panjang mutlak akan diukur dengan menggunakan persamaan sebagai berikut (Effendie, 1997):

$$
\mathrm{L}=\mathrm{Lt}-\mathrm{Lo}
$$

Keterangan :

$\mathrm{L} \quad=$ Pertumbuhan panjang $(\mathrm{mm})$

Lt $=$ Pertumbuhan panjang sesudah pemeliharaan $(\mathrm{mm})$ 
Lo $=$ Pertumbuhan panjang sebelum pemeliharaan $(\mathrm{mm})$

\section{Pertumbuhan Berat Mutlak}

Pertumbuhan berat mutlak akan

diukur dengan menggunakan persamaan sebagai berikut (Effendie, 1997):

$$
\mathrm{W}=\mathrm{Wt}-\mathrm{Wo}_{\mathrm{o}}
$$

Keterangan :

$\mathrm{W}=$ Pertumbuhan bobot $(\mathrm{g})$

$\mathrm{Wt}=$ Berat ikan saat akhir penelitian (g)

Wo $=$ Berat ikan saat awal penelitian (g)

\section{Kelulushidupan}

Kelulushidupan diperoleh berdasarkan persamaan yang dikemukakan oleh Zonneveld et al. (1991) yaitu:

Keterangan:

$$
\mathrm{SR}=\frac{\mathrm{Nt}}{\mathrm{No}} \times 100 \%
$$

$$
\begin{aligned}
\mathrm{SR}= & \text { Kelangsungan hidup }(\%) \\
\mathrm{Nt}= & \text { Jumlah ikan pada akhir } \\
& \text { penelitian (ekor) } \\
\mathrm{No}= & \text { Jumlah ikan pada awal } \\
& \text { penelitian (ekor) }
\end{aligned}
$$

\section{Laju Konversi Pakan (FCR)}

Laju konversi pakan (FCR)

adalah jumlah pakan yang

dihabiskan. Menggunakan persam-

aan menurut (Effendi 1997):

$$
\mathrm{FCR}=\frac{\mathrm{F}}{(\mathrm{Wt}+\mathrm{Wd}) \mathrm{Wo}}
$$

Keterangan:

$$
\begin{aligned}
\mathrm{FCR}= & \text { Laju konversi pakan } \\
\mathrm{F}= & \text { Jumlah pakan yang diberi- } \\
& \text { kan selama pemeliharaan }(\mathrm{g}) \\
\mathrm{Wo}= & \text { Berat ikan saat awal } \\
& \text { penelitian }(\mathrm{g}) \\
\mathrm{Wt}= & \text { Berat ikan saat akhir } \\
& \text { penelitian }(\mathrm{g})
\end{aligned}
$$

$\mathrm{Wd}=$ Berat ikan mati $(\mathrm{g})$

\section{Retensi Protein}

Retensi protein digunakan untuk mengetahui kandungan protein yang ada di dalam tubuh ikan. Perhitungan retensi protein (RP) dengan menggunakan persamaan menurut Watanabe (1988):

Keterangan:

$$
\mathrm{RP}=\frac{\mathrm{Pt}-\mathrm{Po}}{\mathrm{Pp}} \times 100 \%
$$

RP = Retensi Protein (\%)

$\mathrm{Pt} \quad=$ Protein ikan pada hari ke-t $(\mathrm{g})$

Po = Protein ikan pada hari ke-0 $(\mathrm{g})$

$\mathrm{Pp}=$ Jumlah protein pakan yang dikonsumsi $(\mathrm{g})$

\section{Kualitas Air}

Parameter kualitas air yang diukur meliputi suhu, $\mathrm{pH}$ meter, $\mathrm{DO}$, nitrat, dan fosfat. Suhu diukur menggunakan thermometer, $\mathrm{pH}$ diukur mengguna-kan kertas $\mathrm{pH}$, dan DO diukur menggunakan DO test-kit. Pengukuran dilakukan pada setiap perlakuan dengan frekuensi 7 hari sekali.

\section{Analisis Data}

Data pertumbuhan panjang mutlak, pertumbuhan berat mutlak, SR (Survival Rate), laju konversi pakan (FCR) serta retensi protein pada ikan jelawat diuji homogenitas dan normalitasnya. Data yang telah homogen dan normal diolah dengan sistem analisis sidik ragam (Anova) untuk mengetahui pengaruh pemberian enzim fitase terhadap pertumbuhan dan kelangsungan hidup benih ikan jelawat. Apabila berbeda nyata antar perlakuan maka diuji lanjut dengan uji Duncan pada tingkat kepercayaan 95\%. Adapun 
kualitas air dianalisis secara deskriptif.

Hasil dan Pembahasan

Pertumbuhan Panjang Mutlak

Hasil pengamatan setiap minggunya dapat dilihat pada Gambar 1.

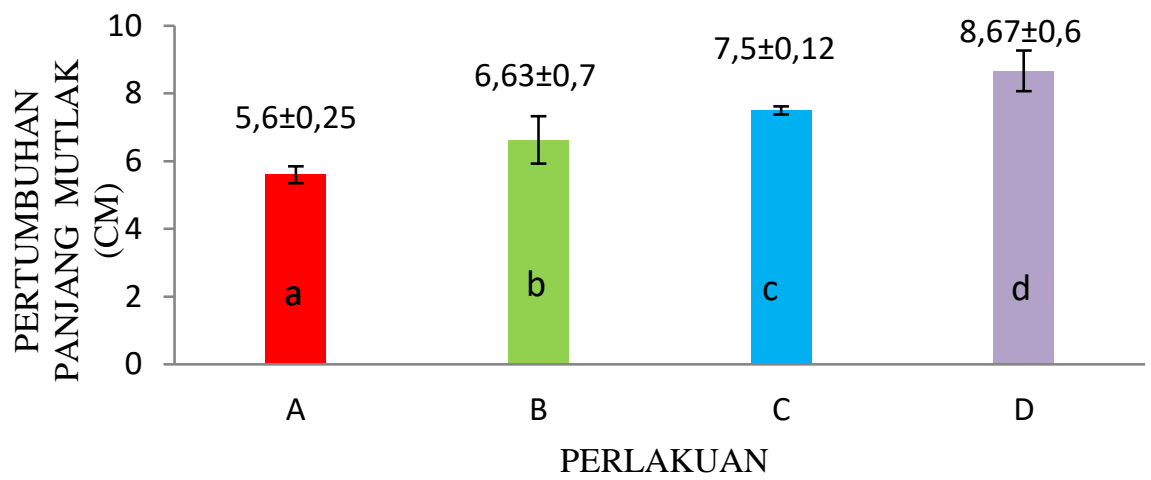

Keterangan: huruf kecil yang sama pada histogram menunjukkan perlakuan tidak berbeda nyata Gambar 1. Pertumbuhan Panjang Mutlak Ikan Jelawat

Berdasarkan data pertumbuhan panjang mutlak ikan jelawat nilai tertinggi yaitu pada perlakuan D 8,67 $\pm 0,6 \mathrm{~cm}$, kemudian diikuti pada perlakuan $\mathrm{C}$ yaitu $7,5 \pm 0,12 \mathrm{~cm}$, perlakuan B yaitu $6,63 \pm 0,7 \mathrm{~cm}$, dan terendah pada perlakuan A tanpa enzim fitase yaitu $5,6 \pm 0,25 \mathrm{~cm}$. Hasil analisis sidik ragam (Anova) menunjukkan bahwa pemberian enzim fitase pada ikan jelawat berpengaruh terhadap pertumbuhan ikan jelawat.

Suplementasi fitase dalam pakan mampu menghidrolisis asam fitat sehingga meningkatkan ketersediaan nutrien, ketersediaan mineral, protein, asam amino, dan kompleks ion kofaktor enzim yang dibutuhkan untuk aktivitas enzim. Asam amino berperan untuk menyusun jaringan tubuh dan berperan dalam pertumbuhan, sehingga dengan peningkatan ketersediaan asam amino ini meningkatkan pertumbuhan dan pertambahan panjang badan ikan.

Suplementasi fitase dalam pakan mampu meningkatkan pemanfaatan ketersediaan asam amino terutama metionin responsif terhadap penambahan enzim fitase dalam pakan sehingga meningkatkan kecernaan asam amino dan rasio efisiensi protein sehingga meningkatnya kinerja pertumbuhan, dapat dilihat pada perlakuan D menunjukkan hasil yang lebih baik karena ikan jelawat mampu memanfaatkan pakan dengan baik.

Pertumbuhan merupakan perubahan ukuran yang terjadi baik dalam berat, panjang, maupun volume selama periode waktu tertentu akibat pembelahan sel yang terdapat pada bagian terbesar dari makhluk hidup.

Pertumbuhan Berat Mutlak 
Hasil pengamatan berat ikan jelawat setiap minggunya dapat dilihat pada Gambar 2.

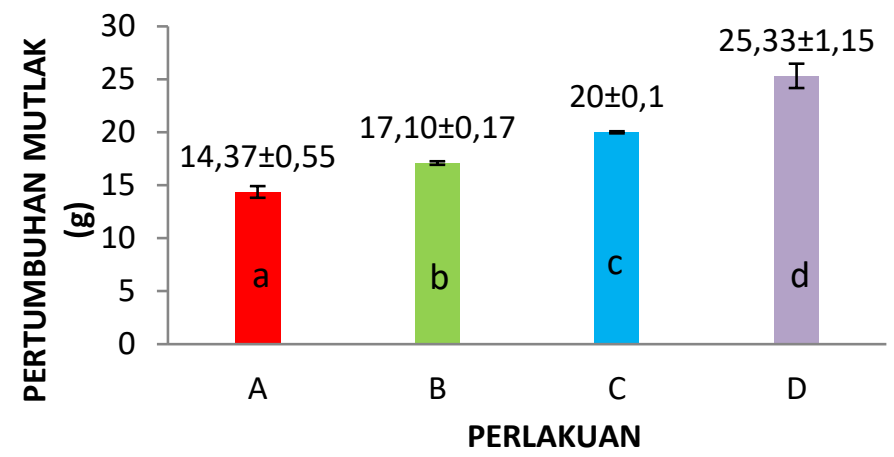

Keterangan: huruf kecil yang sama pada histogram menunjukkan perlakuan tidak berbeda nyata Gambar 2. Pertumbuhan Berat Mutlak Ikan Jelawat

Asam fitat diurai menjadi inositol dan asam fosfat. Inositol adalah salah satu vitamin yang dibutuhkan ikan. Seperti yang diungkapkan Rachmawati dan Samidjan (2014) bahwa inositol merupakan salah satu vitamin yang diperlukan untuk pertumbuhan normal tubuh, pemeliharaan serta reproduksi. Pada perlakuan D menunjukkan hasil pertumbuhan yang lebih baik karena ikan dapat memanfaatkan inositol sebagai vitamin yang diperlukan untuk pertumbuhan sehingga pada perlakuan D ikan dapat tumbuh dengan maksimal. Gejala kekurangan inositol yaitu berkurangnya nafsu makan, lambatnya pengosongan lambung, anemia, dan pertumbuhan menjadi lambat.

\section{Kelulushidupan}

Hasil pengamatan kelulushidupan ikan jelawat yang diperoleh selama penelitian dapat dilihat pada Gambar 3.

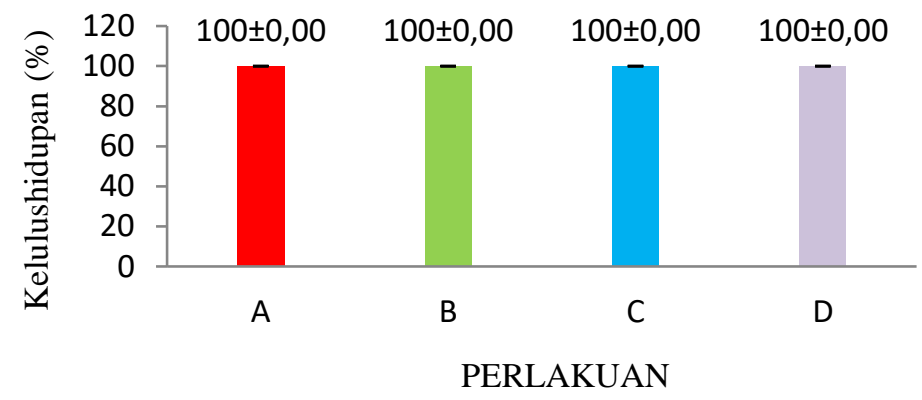

Gambar 3. Kelulushidupan Ikan Jelawat

Berdasarkan hasil penelitian selama 70 hari diperoleh hasil SR sebesar $100 \%$ pada setiap perlakuan dikarenakan tidak ada ikan yang

mengalami kematian. Hasil analisis sidik ragam (Anova) menunjukkan bahwa pemberian enzim fitase pada 
ikan jelawat tidak berpengaruh terhadap kelulushidupan ikan jelawat.

Dari hasil penelitian yang telah dilakukan dapat disimpulkan bahwa lingkungan serta perlakuan pemberian pakan yang mengandung enzim fitase dengan dosis berbeda tidak mengganggu tingkat kelangsungan hidup ikan jelawat.

\section{Laju Konversi Pakan (FCR)}

Hasil perhitungan laju konversi pakan (FCR) dapat dilihat pada Gambar 4.

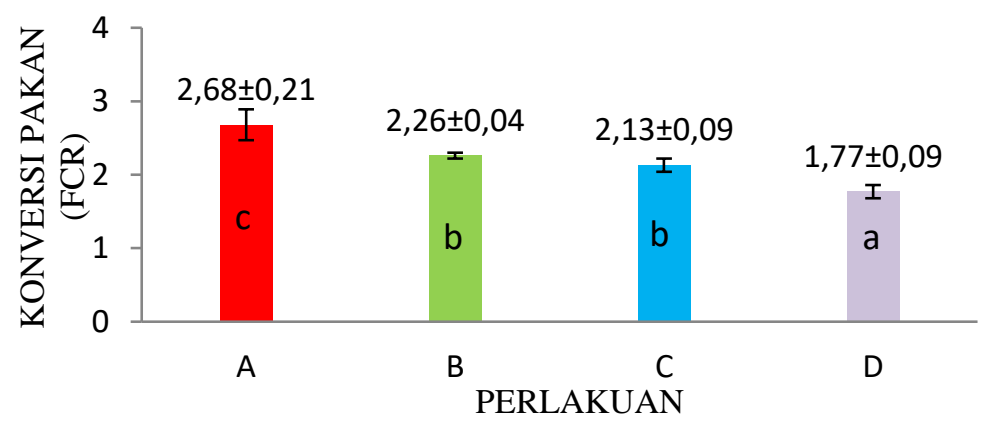

Keterangan: huruf kecil yang sama pada histogram menunjukkan perlakuan tidak berbeda nyata Gambar 4. Konversi Pakan Ikan Jelawat

Berdasarkan data laju konversi pakan ikan jelawat nilai terbaik pada perlakuan D yaitu $1,77 \pm 0,09$, kemudian diikuti perlakuan $\mathrm{C}$ yaitu $2,13 \pm 0,09$, perlakuan B yaitu 2,26 \pm 0,04 , perlakuan A tanpa enzim fitase yaitu $2,68 \pm 0,21$. Hasil analisis sidik ragam (Anova) menunjukkan bahwa pemberian enzim fitase pada ikan jelawat berpengaruh terhadap laju konversi pakan ikan jelawat.

Hasil menunjukkan pemberian enzim fitase pada ikan jelawat dengan dosis D $750 \mathrm{mg} / \mathrm{kg}$ pakan merupakan dosis yang menunnjuk-kan hasil yang baik. Hasil penelitian pada perlakuan D menunjukkan hasil FCR yang terbaik bila dibandingkan dengan perlakuan A tanpa penambahan enzim fitase.
Rendahnya nilai FCR pada perlakuan D (750 $\mathrm{mg} / \mathrm{kg}$ pakan $)$ dipengaruhi oleh enzim fitase yang mampu memecah asam fitat yang menghambat penyerapan nutrisi. menurut Rachmawati dan Hutabarat (2006), mengungkapkan bahwa enzim fitase merupakan suplemen yang diperlukan untuk membantu penyerapan dan pemanfaatan nutrien yang dihambat oleh zat anti nutrisi, sehingga nutrien mampu dimanfaatkan secara maksimal di dalam tubuh ikan.

\section{Retensi Protein}

Hasil perhitungan retensi protein ikan jelawat lebih jelasnya dapat dilihat pada Gambar 5. 


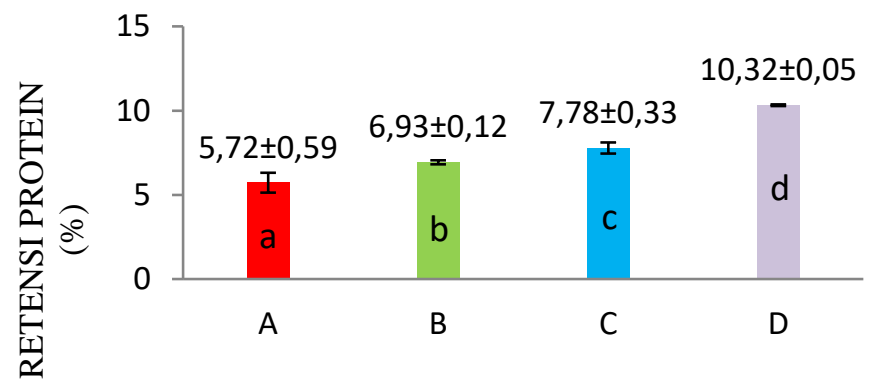

PERLAKUAN

Keterangan: huruf kecil yang sama pada histogram menunjukkan perlakuan tidak berbeda nyata Gambar 5. Retensi Protein Ikan Jelawat

Berdasarkan data retensi protein, nilai tertinggi terdapat pada perlakuan D yaitu $10,32 \pm 0,05 \%$, kemudian diikuti perlakuan $\mathrm{C} 7,78 \pm$ $0,33 \%$, perlakuan B $6,93 \pm 0,12 \%$, dan perlakuan A yaitu 5,72 $\pm 0,59 \%$. Hasil analisis sidik ragam (Anova) menunjukkan bahwa pemberian enzim fitase pada ikan jelawat berpengaruh terhadap retensi protein ikan jelawat.

Perlakuan D merupakan dosis yang efektif karena protein menghasilkan asam amino yang tinggi sehingga banyak yang dapat diserap oleh tubuh ikan. Tingginya retensi protein disebabkan enzim fitase yang terdapat dalam pakan mampu menurunkan dan dapat memutuskan ikatan asam fitat dengan protein dan mineral kompleks. Hal ini akan memberikan pengaruh terhadap enzim pencernaan khususnya enzim pemecah protein dalam menguraikan protein menjadi asam amino penyusunnya

Pertumbuhan ikan yang lambat disebabkan karena kandungan energi pakan khususnya yang berasal dari karbohidrat dan lemak tidak cukup untuk proses metabolisme. Akibatnya protein digunakan untuk proses tersebut, sehingga protein dalam pakan tidak mencukupi bagi ikan untuk proses pertumbuhan. Hal tersebut yang menyebabkan nilai retensi protein ikan rendah.

\section{Kualitas Air}

Hasil pengukuran kualitas air selama pemeliharaan dapat dilihat pada Tabel 1.

Tabel 1. Kualitas air Pemeliharaan

\begin{tabular}{lcc}
\hline Parameter & $\begin{array}{l}\text { Hasil } \\
\text { Pengamatan }\end{array}$ & $\begin{array}{l}\text { Nilai } \\
\text { Optimal }\end{array}$ \\
\hline Suhu $\left({ }^{\circ} \mathrm{C}\right)$ & $27-28$ & $25-32^{*}$ \\
$\mathrm{pH}$ & $7-8$ & $6,5-9,5^{* *}$ \\
$\mathrm{DO}(\mathrm{mg} / \mathrm{l})$ & $4,10-4,86$ & $3-6^{* * *}$ \\
\hline \multicolumn{2}{c}{ Sumber: } & $*$ Rusnah $(2004)$ \\
& $* *$ Boyd $(1979)$ \\
& $* * *$ Puslitbangkan (1992)
\end{tabular}

Suhu pada selama penelitian yaitu $27-28{ }^{\circ} \mathrm{C}$ hal menunjukkan bahwa suhu air pada penelitian ini sudah layak untuk pertumbuhan ikan jelawat. Hasil pengukuran $\mathrm{pH}$ selama penelitian yaitu $7-8$ dan merupakan kisaran $\mathrm{pH}$ yang sesuai untuk pertumbuhan ikan jelawat menurut Boyd (1979). Kandungan oksigen terlarut (DO) selama penelitian berkisar antara 4,10 - 4,86 mg/l sudah mencukupi kebutuhan ikan jelawat karena kisaran oksigen terlarut yang baik untuk pertumbuhan ikan jelawat 
antara 3 - $6 \mathrm{mg} / \mathrm{l}$ (Puslitbangkan, 1992).

\section{Kesimpulan dan Saran}

Penambahan enzim fitase pada pakan dengan dosis $750 \mathrm{mg} / \mathrm{kg}$ pakan dapat meningkatkan pertumbuhan Panjang mutlak, pertumbuhan berat mutlak, laju konversi pakan, dan retensi protein pada ikan jelawat.

\section{Daftar Pustaka}

Aryani, N., Z. Zen, H. Syandri, dan Jaswandi. 2009. Study on nutrition of eggs jelawat (Leptobarbus hoeveni). Jurnal Perikanan dan Kelautan, 14(1): 26-36.

Boyd, C.T. 1979. Water Quality in Warmwater Fish Pond. Auburn University Press, Alabama. 359 Hal.

Chung, T.K. 2001. Sustaining Livestock Production and Environment. Food and Agriculture Asia Pacific Development, Singapore. $54 \mathrm{Hal}$.

Effendie, M.I. 1979. Metode Biologi Perikanan. Yayasan Dewi Sri, Bogor. 112 Hal.

Hijriati, K.H. 2012. Kualitas Telur dan Perkembangan Awal Larva Ikan Kerapu Bebek (Cromileptes altivelis, Valenciennes (1998) di Desa Air Naga, Tanjung Pandan, Belitung. Tesis. Program Pascasarjana, Universitas Indonesia, Jakarta. 13-14 Hal.

Hossain, M.A. dan K. Jauncey. 1993. The Effects of Varying Dietary Phytic Acid, Calcium and Magnesium Levels on the Nutrition of Common Carp, Cyprinus carpio. dalam: (S.J. Kaushik, dan P. Luquet. (Eds.), Fish Nutrition in
Practice. INRA Editions, Paris. 705-715 Hal.

Kosim, M., D. Rachmawati, dan I. Samidjan. 2016. Pengaruh penambahan enzim fitase dalam pakan buatan terhadap laju pertumbuhan relatif, efisiensi pemanfaatan pakan dan kelulushidupan lele sangkuriang (Clarias gariepinus). Journal of Aquaculture Management and Technology, 5(2): 26-34.

Kumar, V., A.K. Sinha, H.P.S. Makkar, G. De Boeck, dan K. Becker. 2011. Phytate and Phytase in Fish Nutrition. Journal of Animal Physiology and Animal Nutrition, 96(3): 335-364.

Puslitbangkan. 1992. Teknik Pembesaran Ikan Jelawat (Leptobarbus hoevenii Blkr) Secara Terkontrol. Departemen Pertanian, Badan Litbang Pertanian, Jakarta. 11 Hal.

Rachmawati, D. dan J. Hutabarat. 2006. Efek Ronozyme $\mathrm{P}$ dalam pakan buatan terhadap pemanfaatan pakan dan pertumbuhan ikan kerapu macan (Epinephelus fuscoguttatus). Jurnal Ilmu Kelautan, 11(4): 193200.

Rachmawati, D. dan I. Samidjan. 2014. Penambahan Fitase dalam Pakan Buatan sebagai Upaya Peningkatan Kecernaan, Laju Pertumbuhan Spesifik dan Kelulushidupan Benih Ikan Nila (Oreochromis niloticus). Jurnal Saintek Perikanan, 10(1): 48-55.

Rochmawati, A.M., M. Arief, dan Prayogo. 2016. Penambahan enzim fitase pada pakan buatan terhadap nilai kecernaan protein dan energi ikan baung (Mystus Nemurus) dengan teknik 
pembedahan. Journal of Aquaculture and Fish Health, 6(1): 1-7.

Sunarno, M.T.D. 2001. Strategi pemeliharaan ikan jelawat (Leptobarbus hoevani) dalam keramba mini di Danau Teluk Jambi. Warta Penelitian Perikanan Indonesia, 7(3): 2-9.

Syafriadiman, N.A. Pamukas, dan S. Hasibuan. 2005. Penuntun Praktikum Pengelolaan Kualitas Air. Fakultas Perikanan dan Kelautan Universitas Riau, Riau. 35 Hal. 